\title{
SOSYAL MEDYADA ETİK SORUNLAR
}

\author{
Şerife Öztürk*
}

\section{ÖZET}

Her dönem değişen teknoloji, bir öncekine göre daha farkll, daha ileri düzeyde imkanlar sunmaktadır. Son 10 yılda medya sektöründe yaşanan değişim, Mc Luhan'ın "küresel köy" tanımını adeta ispatlar niteliktedir. Sosyal medyayı da kapsayan ve bütün bilinen farklı ortamları bir araya toplama yetisine sahip yeni medya, bu hızh değişimin en önemli parçasıdır. Birçok imkanı aynı anda sunması, zaman, coğrafi ve fiziki mekanları ortadan kaldırması nedeniyle her kesimde ilgi odağı olan sosyal medya, kullanıcısını hem üretici hem tüketici olarak konumlamaktadır. Bu konumlanma ise etik sorunları beraberinde getirmiş̧ir. Çalışmada, sosyal medya kavrami, sosyal medyanın gelişimi ve özellikleri ele alınmış, bu alanda yaşanan etik sorunlar ile bu sorunlara ilişkin yapılması gerekenler tavsiye niteliğinde sunulmuştur.

Anahtar Kelimeler: Sosyal medya, yeni medya, geleneksel medya, etik

\section{ETHICS ISSUES IN THE SOCIAL MEDIA}

\begin{abstract}
In every age, changing technology offers more advanced facilities different than the previous ones. Changes of the last 10 years in the media industry has almost proved the Mc Luhan's "global village" definition. The new media, that has the ability of including social media, and collecting all the known platforms, is an important part of this fast change. The social media, that attracts interests in every sectors, defines it's followers both as users and consumers; because it presents many offers at the same time, and eliminates the physical, geographical and time related obstacles. This positioning has brought out some ethical problems, too. In this study, the concept of social media, the development of social media and their properties were discussed, and, the ethical problems experienced in this field and the possible answers to these problems were presented.
\end{abstract}

Keywords: Social media, new media, traditional media, ethisc

\section{Gíriş}

İletişim teknolojilerindeki yenilikler, her dönem insanları çok şaşırtmıştır. İnsanlar, bu teknolojik değişimlere şaşırmakla birlikte, yeniliklere de ayak uydurmuşlardır. Ev telefonlarının cep telefonlarına, bilgisayarın internete ve dizüstü hatta cep bilgisayarına dönüşmesiyle hep yeni bir dönem başlamıştır. Ancak son 10 yıldır yaşanan değişim ve yenilikler insanların hayatının merkezi durumuna gelmiştir. Geleneksel medyayı henüz içselleştiren insanların yeni medyadaki teknolojileri kabullenmeleri geleneksel medyaya göre çok daha çabuk olmuştur. Çünkü geleneksel medya, yeni medya teknolojilerine zemini çoktan hazırlamıştir.

\footnotetext{
* Doktora Öğrencisi, Ankara Üniversitesi Sosyal Bilimler Enstitüsü
} 
Yeni medyanın oluşması ve günümüzdeki bu halini alması geçmişte meydana gelen birçok yeniliğin kaçınılmaz sonucu ve niteliğidir. Yeni medya ile coğrafi, fiziki ve zaman engelleri ortadan kalkmış, geniş bilgiye hızlı erişim sağlanmıştır.

Yeni medyanın da içinde barındırdığ 1 "sosyal medya" kavramı, son 10 yıldır insan hayatında çok fazla yer tutmaktadır. Sosyal medya ile çoklu ortamları içinde barındırması sayesinde dünyanın öbür ucunda olan insanlarla anında yüzyüze iletişim kurulabilmekte, fotoğraf, video paylaşımı yapılabilmektedir. Bu durum da, Mc Luhan'ın "küresel köy” teorisinin bir kez daha anlaşılmasını sağlamiştır.

Yeni medya araçları arasında bilgisayar oyunları, CD-romlar, web siteleri, bloglar, e-postalar, elektronik kiosklar, interaktif televizyon, mobil medya, podcastler sayılabilirken, Facebook, Tweeter, İnstagram, Youtube gibi paylaşım siteleri de sosyal medya olarak nitelendirilmektedir.

Sosyal medya, her geçen gün yazılımlarını güncellemekte ve bu sayede de değişen teknolojiye ayak uydurarak hep "yeni" kalmaktadır.

Sosyal medya, insanların tanıdıkları / tanımadıkları pek çok kişiyle iletişime geçebilmesi, eş zamanda binlerce insanla, binlerce mesaj paylaşımında bulunabilmesini sağlamıştır. İnsanların birbiriyle yüzyüze iletişim kurduğu hatta yüzyüze iletişimden çok daha fazla paylaşımda (müzik, video, yazı, fotoğraf, konum bildirme) bulunduğu sosyal medya ortamı, etik ihlalleri ve bunun tartışmasını da beraberinde getirmiştir.

Çalışmanın ilk bölümünde, son 10 yıldır toplumdaki herkesin hayatını değiştiren hatta yönlendiren yeni medya ve sosyal medya kavramı ile sosyal medyanın doğuşu, bu zamana kadarki gelişimi incelenmiş, özellikleri ve geleneksel medyadan ayrılan yönleri ele alınmıştır.

İkinci bölümde etik kavramı genel olarak incelenmiş olup sosyal medyadaki etik sorunlar anlatılmış, etik ihlallerin nedenleri, bunlara karşı alınması gereken tedbirler de yine ikinci ve son bölümde irdelenmiştir.

\section{YENI MEDYA VE SOSYAL MEDYA KAVRAMI}

Yeni medya kavramı insanların hayatına girinceye kadar, 1900'lü y1llardan itibaren, yeni teknolojiler her dönem toplumsal hayatta yerini almış ve bu teknolojilerin bir öncekilere göre daha ileri özelliklere sahip olması insanların hayatını her dönemde kolaylaştırmıştır.

1900’lü yıllarla birlikte teknik keşifler çoğalmış, elektrik, ışık, telgraf, telefon gibi teknik araçların insan yaşamına girmesiyle yazılı dönem yerini, elektrikli ya da elektronik döneme bırakmıştır (Atabek 2005: 63). Dijitalleşmeyle birlikte elektro- 
nik çağ yerini dijital çağa bırakmaktadır. Ancak dijital kavramı bu çağı tam olarak kapsayamamaktadır. Elektronik ve dijital ortamlar yakınsama (bütünleşme) özelliğiyle birlikte bütünleşik bir yapı kazanmaktadır. Bu nedenle içinde bulunulan dönem bilişim çağı olarak ifade edilebilmektedir (Yengin 2012: 51).

Yeni medyayla birlikte dengeler yerinden oynamaktadır. Okuma-yazma kuralları değişmekte ve yeni iletişim dilleri türetilmektedir. Duyuları biçimlendiren ve köklü değişiklikleri sağlayan yeni medya, bireylerin yaşam tarzlarını, iletişim süreçlerini ve daha birçok dinamiklerini değiştirmeye devam etmektedir (Yengin 2012: 114).

Yeni medya kavramı, içinde pek çok "yeniliği" barındırmaktadır. Yeni denilmesi, mesajın değil, ortamın paylaşılmasında getirilen yeniliklerden kaynaklanmaktadır. İletişim teknolojisindeki yenilikler medya kavramını da "yenileştirmiş", en başta interaktif özelliği nedeniyle kullanıcılarını "sosyal" hale getirmiştir.

Yeni medya kavramı, Türkiye'de son birkaç yıldır anılmaktadır ancak dünyada bu kavramın kullanılması daha da geriye gitmektedir. Facebook, Twitter, Google+, LinkedIn, Pinterest, Youtube, Tumblr, İnstagram, Vine, Flickr, Myspace en fazla kullanılan yeni medyalardır.

Sosyal medya ise kişinin kendisinin ürettiği içeriği, yayınladığı ve paylaştığ her türlü platformun genel adıdır (http://www.trendweek.com).

Yeni medya kavramının içinde yer alan sosyal medya, Web 2.0'ın kullanıcı hizmetine sunulmasıyla birlikte, tek yönlü bilgi paylaşımından, çift taraflı ve eş zamanlı bilgi paylaşımına ulaşılmasını sağlayan medya sistemidir. Ayrıca sosyal medya; kişilerin internet üzerinde birbirleriyle yaptığı diyaloglar ve paylaşımların bütünüdür. Sosyal ağlar, insanların birbiriyle içerik ve bilgi paylaşmasını sağlayan internet siteleri ve uygulamalar sayesinde, herkes aradığı, ilgilendiği içeriklere ulaşabilmektedir. Küçük gruplar arasında gerçekleşen diyaloglar ve paylaşımlar giderek, kullanıc bazlı içerik (İngilizce: UGC-User Generated Content) üretimini giderek arttırmakta, amatör içerikleri dijital dünyada birer değere dönüştürmektedir. Zaman ve mekân sınırlaması olmadan, paylaşımın, tartışmanın esas olduğu bir insanî iletişim şeklidir. Teknoloji, telekomünikasyon, sosyal iletişimin kelimeler, görseller, ses dosyaları yolu ile sağlandığı bir yapıya sahiptir. İnsanlar hikâyelerini ve tecrübelerini bu bağlamda paylaştı̆̆ bir çerçeveye de sahiptir. Sosyal medya aynı zamanda "Kullanıcıların Ürettiği İçerik" ve "Müşterilerin Ürettiği Medya" kavramlarını da ortaya çıkarmış, bu yapısıyla da ticari plandaki anlamını kazanmıştır (http://tr.wikipedia.org/w/index.php?title= Sosyal_medya).

Kaplan ve Haenlein'in tespitine göre de, sosyal medya, “Web 2.0 üzerinde ideolojik ve teknolojik içeriklerin, yapılanmaların kullanıcı merkezli bir şekilde üre- 
tilmesine ve geliştirilmesine izin veren internet tabanlı uygulamaların bütünüdür (2010: 59-68).

Sosyal medyada yer almanın nedeni, fark edilmek ve etkileşim yaratmaktır. Sosyal medyanın kuralı, sesini en etkin kanal ve içerikle duyurmak yani fark edilmeyi sağlamaktır.

1978'de ilk sosyal medya girişimi olarak adlandırılan BBS isimli yazılımdan, MIRC'a, ICQ'dan Facebook ve Twitter'a kadar olan günümüz yansımasında, iletişimin sanallıktan kurtulup gerçeğe dönmesi ile birlikte adeta sosyal medya çılgınlığı yaşanmaktadır (Sanlav 2014: 13).

ABD'li ressam, film yapımcısı ve yayıncı Andy Warhol'un “Herkes 15 dakikalığına ünlü olacak" sözü sanki günümüze atfedilmiştir. Bugün herkes kendi videosunu çekip yayınlayabilmekte ve bir şekilde sosyal medyada yerini almaktadır.

\subsection{Sosyal Medyanın Doğuşu ve Gelişimi}

Yeni medya dolayısıyla da sosyal medyanın gelişimi, sahip olduğu teknolojik özellikleri nedeniyle geleneksel medyaya göre daha hızlı olmuştur.

Elektronik veri işleme kapasitesine sahip ilk bilgisayar 2. Dünya savaşı esnasında ABD'li bilim adamları tarafından inşa edilen ENIAC (Electronic Numerical Integrator And Computer - Elektronik Sayısal Entegreli Hesaplayıc1), yaklaşık 167 metrekarelik alana sığmakta ve 30 ton ağırlı̆̆ındaydı. 4 yılda imal edilen ENİAC'ın ilk deneme çalışmasına 1945 yılında başlanmış ve gerçek anlamda çalışması 1947 yılını bulmuştur. ENİAC'ın parçaları şu anda Washington'daki Amerikan Ulusal Müzesinde sergilenmektedir (http://tr.wikipedia.org/wiki/ ENIAC).

Ardından 1960'lı yıllarda soğuk savaş döneminde ABD hükümeti tarafından internet geliştirilmiştir. ABD hükümetinden önce askeri güçler bu ağı kontrol etmekteydi, ancak ABD hükümeti bu ağı merkezsizleştirmiş ve iletişimde kullanılabilir şekle dönüştürmüştür. Böyle bir ağın geliştirilme nedeni, soğuk savaş süresince diğer iletişim araçlarının merkezli olmasından kaynaklanan bir emniyet sorunu olmasıydı (Akter 2009: 93).

Yeni medyanın içinde yer alan "sosyal medya, terim olarak son üç yıl içerisinde hayatımızda yer etmiş olsa da, tarihi 70'li yıllara dayanıyor. Ward Christensen ve Randy Suess, 1978 yılında arkadaşları ile bilgi paylaşımı içerisinde bulunmak, onlarla irtibatta kalmak için BBS isimli bir yazılımı hayata geçirerek (hiç farkında olmasalar da) ilk sosyal ağ örneğini ortaya koymuşlardır. 1994 yılında kurulan GeoCities'in internet kullanıcılarına kendi web sitelerini kurma olanağı sunması ve ilk tarayıc Mosaic ile birlikte 'halka inen' internet 1994 yılında 'Informatin 
Superhighway' olarak tanımlanmaktadır. 1994 yılında ilk sosyal ağ Friends United kurulmuştur"'(http://sosyalmedya.co/sosyal-medyanin-tarihi).

1995 yılında MIRC programı üretilmiştir. MIRC' da takma isimli (nickname) kullanıcılar, tanımadıkları kişilerle de iletişim kurmuşlardır. Kullanıcılar kendileri hakkında detaylı bir bilgi vermek zorunda değillerdi fakat iletişim kurdukları kişi hakkında da net bilgiler alamıyorlardı. Ardından gelen ICQ programı ile tanınan kişiler bir anlamda bir araya toplanmış oldu. ICQ'da da isim kullanılmazken, programın verdiği kullanıcı numaraları ICQ kimliklerini oluşturmuştur (Sanlav 2014: 20-21).

1997 yılında Google kurulmuş, AOL'nin anlık mesajlaşma servisi yayına girmiştir. 1995 yılında dünya üzerinde toplam web sitesi sayısı 1 milyona ulaşmıştır (http://sosyalmedya.co/sosyal-medyanin-tarihi).

1999 yılında Windows Live Messenger kullanılmaya başlanmıştır ve bu program 2013 yilında Skype'a dönüşmüştür (http://www.teknolojioku.com).

Ludicorp tarafından 2004 yılında geliştirilen ve fotoğraf paylaşım sitesi olan Flickr, Nisan 2008'de video paylaşımına da izin vermeye başlamıştır. Eylül 2010 verilerine göre 5 milyardan fazla fotoğrafı barındırmaktadır (http://tr.wikipedia. org).

Son yıllarda oldukça popüler olan hemen hemen herkesin hesabının bulunduğu Facebook, 4 Şubat 2004 tarihinde Harvard Üniversitesi öğrencisi Mark Zuckerberg tarafindan kuruldu. Mark Zuckerberg Facebook'u kurmadan önce Harvard kampüsünde öğrencilerin fotoğraflarını karşılaştıran Facemash sitesini kurmuştu. Mark Zuckerberg bu platformdan esinlenerek Facebook'u Harvard Üniversitesi'nde hayata geçirdi. Kısa sürede öğrenciler arasında ilgi gören Facebook Boston civarındaki üniversitelere yayıldı. Birkaç ay içinde ABD'deki seçkin üniversiteleri temsil eden Ivy League üniversiteleri içinde kapalı devre bir hale geldi. 11 Eylül 2006 tarihinde ise Facebook tüm e-mail adreslerine, bazı yaş sınırlandırmalarıyla açıldı. Kullanıcılar diledikleri ağlara; liseleri, çalışma yerleri ya da yaşadığ1 yerler itibariyle katılım gösterdi. 2007 Temmuz ayı itibariyle de; 34 milyon kullanıcısıyla dünyanın en büyük Üniversite tabanlı kullanıcılarına sahip oldu. Alexa istatistiklerine göre Facebook 20 Ekim 2007 itibariyle; Dünya'nın en fazla ziyaret edilen 7'inci sitesi olmayı başardı. Kısa sürede Facebook Kanada, Güney Afrika ve Norveç'in en fazla ziyaret edilen sitesi; İngiltere ve İsveç'in 2. en fazla ziyaret edilen sitesi, Mısır ve Panama'nın 3., Amerika Birleşik Devletleri, Avustralya ve Türkiye'nin de 5 . en fazla ziyaret edilen sitesidir (http://www.sabah.com.tr).

2006 yılında kurulan YouTube da sosyal paylaşım mecrasının video ayağını oluşturarak, bu alana çok büyük bir katkı yapmıştır. 2006 yılında hayatımıza giren 
mikro blog sitesi Twitter, kısa zamanda kendi kültürünü ve kendi ünlülerini de oluşturmuştur (Sanlav 2014: 23).

\subsection{Sosyal Medyanın Temel Özellikleri}

Mavnacıoğlu (2009: 64), sosyal medyanın özelliklerini şu şekilde sıralamaktadır:

- Zaman ve mekan sınırlaması olmadan, paylaşımın ve tartışmanın esas olduğu bir internet uygulamaları zinciridir.

- Bireyler, kendi ürettikleri içerikleri çok kolay bir şekilde internet ortamında ve mobil ortamda yayımlamaktadır.

- Bireyler, başka kullanıcıların içeriklerini, yorumlarını takip etmektedirler.

- Birey, hem takip eden hem de takip edilendir.

- Temeli, kuralları belirlenmiş bir iletişime değil samimi bir sohbet mantığına dayanir.

- İçerikler detaylı incelendiğinde informel oldukları ve zamanla kullanıcılar arasında bir dedikodu zincirine dönüşebildiği görülmektedir.

\subsection{Sosyal Medya ve Geleneksel Medyanın Yapısal Anlamda Farkları}

Sosyal medyanın hayatımıza girmesiyle birlikte geleneksel medyaya olan ilgi kaymış, ancak yine de geleneksel medyaya olan rağbet tamamen ortadan kalkmamıştır. Sosyal medyaya olan ilginin başlıca sebebi, bu teknolojiyi geleneksel medyadan ayıran birtakım özellikleridir. Bu özellikler şu şekilde sıralanabilir:

Dijitallik: Sosyal medyayı geleneksel medyadan ayıran bu özelliği, kullanıcı kaynaklı yani üre-tüketici olmasıdır.

Dijitallikten dolayı, yazar-okur, performe eden ve izleyen, yaratıcı ve yorumcu arasındaki fark silinmekte, nihai alıcının bir diğerinin etkinliğine katkıda bulunabileceği bir yapı içerisinde bulunmakta, böylece nihai imza ortadan kalkmaktadır (Levy 1998'den akt. Lister ve ark. 2009).

Dijitalleşmenin en önemli özelliklerinden biri de yöndeşme olgusudur (Hodkinson 2011'den akt. Yengin 2012: 84). Yöndeşme; bilgisayar, görsel-işitsel medya, telekomünikasyon gibi sektörlerin teknolojik ve ekonomik olarak birleşmesi, yeni ürünler ve hizmetler meydana getirmesi, farklı iletişim platformlarının temel olarak benzer türde hizmetleri taşıyabilmesi olarak tanımlanabilir. 
Etkileşimsellik: Etkileşim her yerde hazır olma durumu olarak tanımlanmaktadır. Etkileşim yeni medyada bireylerin veri alışverişine devam etme durumudur. Burada önemli olan bireyin veri üzerindeki etkisi, devamlılığı olmaktadır (Yengin 2012: 85).

Alıcının kaynak, kaynağın da alıcı olması, bu sürecin aynı zamanda alıcıyı iletişim sürecinde etkin kılması ve bu işlemlerin tek kanal üzerinde gerçekleşmesidir.

Etkileşimsellik, kullanıcıların bilgi kaynaklarına ulaşmada daha seçici olabilmesini sağlaması ve diğer kişilerle etkileşime olanak tanıması bakımından sosyal medya ağlarının en önemli özelliklerinden biridir. Etkileşimsellik özelliğiyle, kullanıcılara seçici bir biçimde içerik oluşturma, arama, paylaşma ve diğer bireyler ya da gruplarla etkileşime girme imkânını, geleneksel medyanın sağlayamayacağı ölçüde verir (Lievrouw ve Livingstone 2007: 25).

Etkileşimsellik özelliği, iletişim sürecine iletişim uzamında karşılıklılık veya çok katmanlı iletişim olanağını kazandırmıştır. Etkileşimsellik özelliğinin iletişim sürecine ilişkin dönüştürücü etkisi de, iletişimin zamanında eşanlı olma derecesine ilişkin yaptığı açılımdır. Sosyal medyanın bu özelliği, geleneksel medyaya göre kullanıcının iletişim sürecindeki rolünü ve katılımını da çeşitli şekillerde etkilemektedir (van Dijk 2004: 146)

Sosyal medyada, birden fazla kullanıcının sanal ortama dalması durumunda söz konusu ortam, kullanıcıların avatarlarının (arayüzeyde kişiyi temsil etmek için yaratılan karakter ve/veya profile verilen isim) da birbirleriyle etkileşim içinde olabildiği ortak bir dünya haline gelir (de Mul 2008, Burnett 2007'den akt. Binark ve Löker 2011: 10).

Etkileşimsellik özelliği ara yüzeydeki farklı kullanıcıların birbirleriyle iletişim kurmalarına olanak sağlar. Sosyal medyayı cazip kılan, her kesimden insanların kullanmasına olanak veren en önemli özelliği, etkileşimselliktir.

Multimedya biçimselliği: Ses, metin, görüntü ve sayısal veri gibi farklı medya özelliklerini bir arada bulundurabilmesi özelliğidir.

Multimedya biçimselliği telekomünikasyon, veri iletimi, kitle iletişimi gibi iletişimin farklı boyutları ile imge, ses, metin ve sayısal veri gibi farklı veri türlerinin bir arada bulunmasıdır. Sosyal medyanın depolama kapasitesinin de yüksek olması, kullanıcının seçiciliğini desteklemektedir (Binark 2007: 22). *Hipermetinsellik: Hipermetin, belirli bir birimden diğer birimlere giden sayısız yoldan oluşan bir yapı olarak tanımlanabilir. Ağdaki her bir parçanın sayısız giriş ve çıkışları veya bağlantıları vardır. Böyle bir teknolojinin kullanılmasıyla, herhangi bir veri noktası, diğer noktalara anında ulaşılabilmesini olanaklı kılan sayısız bağlantıyı üzerinde barındırabilir (Lister ve ark. 2009: 26). 
Hipermetinsellik, 'www' (world wide web) üzerine kurulu bulunan yapısal oluşumdan oluşmaktadır. Bir metnin başka metinlerle olan ilişkisi anlamına gelmektedir. Hipermetinsellik özelliğiyle birlikte ağ üzerinden başka alternatif mecralara kolayca erişim gerçekleşmektedir (Binark ve Löker 2011: 12). Sosyal medya içerisinde kullanılan verilerden oluşan metinlerin farklı dijital yapı sistemleri içinde kullanılma durumu hipermetin olarak ifade edilmektedir. Bu ortamlar sınırsız bir kullanım alanına sahip olmaktadır. Hipermetin özelliğiyle birlikte veri toplama, paylaşma ve bu verileri güncelleme olanakları artmaktadır (Yengin 2012: 86).

Kullanıcı türevli içerik üretim (üre-tüketici): Sosyal medya kullanıcılar1nın/tüketicilerinin birbirleriyle ağ üzerinden iletişim kurması, ortak tüketimin yanı sıra ortak üretimi de olanaklı kılmaktadır. Kullanıcılar takip ettikleri içerikleri, bireysel veya kolektif olarak değiştirebilmekte ya da kendileri doğrudan içerik yaratabilmektedirler. Bu da, sosyal medya kullanıcılarını fiziksel olmasa da sanal olarak yakınlaştırmaktadır.

Bahsedilen bu "yakınlaşma", teknolojik bir süreç değil, izleyici davranışının bir özelliğidir. Diğer bir deyişle yakınlaşan kullanıcının kendisidir (Jenkins 2006).

"Kullanıcı türevli içerik, büyük sosyal etkiler barındıran bir olgudur. Kullanıcıların enformasyon üretimi, dağıtımı, erişimi ve yeniden kullanım biçimlerindeki değişim ile kullanıcı özerkliği, katılım, çeşitlilik ve yaratıcılık artmıştır. Kullanıcı türevli içerik ayn zamanda kişilerin bilgi-iletişim teknolojileriyle ilgili yeteneklerinin gelişmesini sağlar. Açık bir platform olduğundan, kullanıcı türevli içerik, politik ve sosyal tartışmaları zenginleştirip düşünce çeşitliliğini genişletirken enformasyonun serbest akışını ve ifade özgürlüğünü de arttırır" (OECD 2008:5).

"Kullanıcı türevli içerik üretimi bireylerin yeni medya okuryazarlığı ile ilgili becerilerinin de gelişmesini sağlamaktadır. Bu özellik bireyin ifade özgürlüğünü de artırır ve zenginleştirir" (Binark ve Löker 2011: 11).

Andy Warholl'un “Herkes 15 dakikalığına ünlü olacak” sözü, sosyal medyanın kullanıcı türevli içerik üretim özelliği sayesinde gerçekliğini bulmaktadır.

Yayılım: Sosyal medya uygulamaları, bütün yeni medya araçları gibi, ağ destekli uygulamalardır. Söz konusu bu ağ, çoğunlukla internet gibi büyük ve genel bir ağ olsa da özel ağlar üzerinden işleyebilen uygulamalar da bulunabilir. "Ağ kavramı en temel tanımıyla belirli düğümlerin birbirleriyle bağlantılar aracılı̆̆ıyla iletişim içinde olduğu sistemleri ifade eder" (Coleman 2012: 16).

Yayılım özelliği, ağ üzerinde yer alan sunucularla mümkün olabilmektedir. Çok sayıda giriş ve çıkış bağlantısı bulunması nedeniyle sunucu, çemberin merkezini değil, ağ üzerindeki tek bir parçayı oluşturur. A $\breve{g}$ temelli yayılım sayesinde çok 
sayıda kullanıcı, çok farklı zamanda, çok farklı içeriğe ulaşabilmektedir (Lister ve ark. 2009: 33).

Sosyal medyada paylaşılan içeriklere başka bir zaman yeniden ulaşmak ve o içeriği tekrar dolaşıma sokmak mümkündür. Örneğin Facebook'ta dolaşıma sokulan bir fotoğraflı metin çok kısa süre içerisinde sosyal ağ ile paylaşılır. Kullanıc1nın ortama yüklediği o içerik, kendi sosyal ağında bulunan başka bir kullanıcı tarafından kendi sayfasında paylaşılarak yayılır. Birbiri ile bağlantılı bu ağlar sayesinde içeriğin milyonlarca kullanıcıya yayılımı gerçekleşir (http://www.ahmetcetinkaya.com).

Yayılım özelliği, bir video, fotoğraf veya haberin / metnin en kısa zamanda milyonlarca kişiye ulaşmasını sağlaması açısından hızlı olma özelliğini gözler önüne sermektedir. Bu özellik, hipermetinselllik özelliğinden beslenir. Kullanıcılar, tüketici durumdayken içeriği paylaşarak içeriği üretici konuma geçerler ve yayılımını sağlamış olurlar.

Sanallık/ Arayüzde mevcudiyet hissi: 1990'lardan başlayarak, "sanallık" denildiğinde akıllara gelen imge, sanallığın kendisine ait değil, bunu tecrübe eden bir kişi ve kullandığ1 ekipmanlara ait olmuştur (Lister ve ark. 2009: 35-36).

Sosyal medyanın sanallık özelliği, "arayüzey ile kullanıcının kurduğu iletişimin niteliğini açıklamaktadır. Sanallık, kullanıcıya orda olma hissini sağlar (Binark ve Löker 2011: 12).

Sosyal medya; kullanıcı türevli, dijital etkileşimli, hipermetinsel, sanal ve ağ bağlantılı özellikleriyle bireylerin yaşamına girmeyi başarmıştır (Yengin 2012: 88).

\subsection{Sosyal Medya ve Geleneksel Medyanın Ticari Anlamda Farkları}

Sosyal medya ve geleneksel medya yapısal anlamda birbirlerinden farklılık gösterdiği gibi ticari anlamda da birbirlerinden ayrılmaktadır.

Sosyal medya ve geleneksel medyanın ticari anlamda birbirlerinden farkları şunlardir:

- Reklam hedeflemesi çok daha keskindir. Örneğin; Bir şirketin hedef kitlesinde 18-25 yaş grubu, bekar, erkek, üniversite mezunu, pop müziğe ilgi duyan kişiler olduğunu varsayarsak bu hedeflemelerin tamaminı Facebook reklam hedeflemeleriyle yaparak direkt bu kişilere ulaşılabilir (http://dijitalkulturgra331.blogspot. com.tr).

- Hem maliyet hem de zaman tasarrufu sağlar. Hesap açan herkes sosyal medya üzerinden yayın yapabilir. Sosyal medyada maliyet geleneksel medyaya göre daha düşüktür. Ürettiği veya paylaştığı içeriğin kalitesine ve ilgi çekiciliğine göre milyonlara ulaşabilir (Sanlav 2014: 36-43). 
- Geleneksel medyada bir haber oluşturulduktan sonra değiştirilemez, ancak ertesi gün düzeltmesi yayınlanabilir. Fakat durum yeni medyada böyle değildir. Yanlış bir blog yazısı yazılırsa hemen güncellenebilir (Sanlav 2014: 36-43).

- Geleneksel medyanın okuyucuları, bu medyadaki herhangi bir haberle, haber yazarıyla anlık olarak iletişime geçemez. Okuyucu, yazara e-mail gönderip sadece bu okuyucu ve yazar arasında bir etkileşim olacak şekilde iletişime geçebilir. Fakat sosyal medyada okuyucu bir yazarın yazısına kendi yorumunu da ekleyerek Twitter veya Facebook hesabında paylaşabilir; o yazının altına yorumunu ekleyebilir ve hatta yazar sayfasında Facebook yorum eklentisi kullanmışsa bu yorumunu kendi Facebook profilinin duvarında otomatik olarak paylaşarak tüm Facebook kullanıcılarının haberdar olmasını sağlayabilir (http://dijitalkulturgra 331.blogspot.com.tr).

- Geleneksel medyada yazılan her makale, yapılan her haber bir denetim sürecinden geçer, onay verilmeyen yazılar yayınlanmaz. Sosyal medyada ise bir yazının, resmin, videonun yayınlanıp yayınlanmaması tamamen kullanıcıya kalmış ve denetim aşaması rafa kaldırılmıştır. Yine geleneksel medyada kurumlardanhalka şeklinde bilgi aktarımı gerçekleştirilmektedir. Fakat şimdi sosyal medyada durum genişleyerek, kurumdan-halka, halktan-halka, halktan-kuruma olarak şekillenmektedir (Sanlav 2014: 36-43).

- Geleneksel medyanın araçlarını yani bir gazetenin köşesini ya da bir reklam alanını kullanmak için belli bir statüde, belli bir eğitimde olmak veya belli bir şirket arkasında olmak gerekmektedir. Ancak sosyal medyada yayın yapmak isteyen herkes yer alabilir. Herhangi bir eğitim gerekliliği bulunmamaktadır (http://dijitalkulturgra331. blogspot.com.tr).

- Ayrıca geleneksel medyada geçmişe yönelik bir haberi bulabilmek, kısacası "arşive ulaşabilmek" çok zor bir olaydır. Fakat günümüzde yeni medya teknolojilerinin kullanıldığı sosyal medya mecrasında arşive ulaşmak çok daha kolay hale gelmiştir (Sanlav 2014: 36-43).

- Geleneksel medyada yayınlanan resim veya yazılarda, zamanı belli olmadan, sinırlı sayıda yoruma yer verilmektedir. Sosyal medyada ise bir haber, video ya da bir resim, gerçek zamanlı bir şekilde, yorum sınırı olmadan etkileşimi en üst seviyede okuyucu ya da izleyici ile buluşabilmektedir. Bu da sosyal medyanın geleneksel medyaya nazaran çok daha interaktif bir hal almasını sağlamaktadır.

Sosyal medya ve geleneksel medya, arasındaki tanımların farklı olmasına, sosyal medyanın geleneksel medya önüne geçtiğinin söylenmesine ve geleneksel medya arasında haber paylaşımında birtakım sıkıntılar yaşanmasına rağmen aslında birbirlerini besleyen, destekleyen ve büyümelerini hızlandıran iki medya alanıdır. Geleneksel medyanın beslenmesine en büyük katkıyı sağlayan televizyon, şu 
anda Twitter ve Facebook'u da beslemektedir. Sosyal medya erişilebilirliğinin kolay olması, bu mecrayı kullanmak için herhangi bir yeterliliğe sahip olmanın gerekmemesi sebebi ile bir adım önde gibi görünse de geleneksel medyanın beslenmesine en büyük katkısı olan televizyonun yerini alacak gibi görünmemektedir (Sanlav 2014: 41-42).

\section{SOSYAL MEDYADA ETİK SORUNLAR}

\subsection{Etik Kavramı}

Etik, pek çok düşünür, yazar ve bilim insanı tarafından tanımlanmış bir kavramdır ve felsefenin en eski disiplinlerinden biri olarak kabul edilmektedir.

Etik kelimesi köken olarak Eski Yunan'a kadar gider. Etik kavramı Yunanca, karakter ve davranış anlamına gelen "etos" sözcügünden türetilmiştir. Ahlaki, ahlakla ilgili olarak tanımlanır. Fakat ahlak ve etik arasında fark bulunmaktadır (Çavdar 2009: 163). Etik, evrensel kabul gören kurallardır (www.meb.gov.tr).

Etik sözcügüüün, köken ve anlamında "töre" ve "gelenek" dikkat çekici bir belirginlik göstermektedir. "Kelime kökü (ethos) 'töre', 'gelenek' anlamina geldiğinden törebilim de denilmektedir" (Tevrüz 2007'den akt. Gürel 2009: 176).

Etik, toplumda bir arada yaşayabilmek için insanlara yol gösteren ahlak normlarını içermektedir. O halde etik "ahlaki açıdan kabul edilebilir bireysel, kurumsal ve toplumsal değerlerin tanımlanması ve bu değerlerin insan davranışını değerlendirmenin temel kıstası olarak kullanılması" (Demir 2006: 25) olarak ifade edilebilir.

Bireysel ve kurumsal etiğin hizmet ettiği amaç aynı gibi görünmektedir. Seitel etiği bir kişi, örgüt ya da toplum için doğru ile yanlış, haklı ile haksız, dürüst olan ile olmayan gibi değerlerin farklarını anlamamıza rehberlik etmek olarak tanımlamaktadır (2001'den akt. Gürel 2009). Wilson ise, spesifik durumlarda uygun davranışa karar vermek için kullanılan kurumsal, profesyonel ve sosyal standartlar olarak ifade etmektedir (2000'den akt. Gürel 2009: 177).

"Etik, ahlaki açıdan kabul edilen bireysel, kurumsal ve toplumsal değerlerin tanımlanması ve bu değerlerin insan davranışlarının değerlendirilmesinde temel ölçü olarak kullanılması şeklinde tanımlanabilir" (Seib ve Fitzpatrick 1997'den akt. Erol 2009: 36).

Retief'e göre, genel olarak uygarlık tarihinde üç farklı etik anlayıştan söz etmek mümkündür (2002'den akt. Erol 2009: 36):

1. Antik Yunan Filozofu Aristo, Altın Denge kuramını önermektedir. Aristo'ya göre erdem, aşırı iki uç arasında denge kurabilmektir. Bu denge etiğe işaret eder. 
Örnek olarak, Web'de İran'da yaşanan alternatif idam haberini alacak olursak ne bu haberi saniye saniye idam anına yakın çekim yaparak vermek ne de bir cümle ve belki de fotoğraf değeri taşımayan bir görüntü ile vermek etiktir. Bu iki aşırı uç arasında denge sağlamak gerekmektedir.

2. Alman Filozof Immanuel Kant da Görevci Etik Anlayışını önerir. Bu kuramda önceden belirlenmiş davranış ilkeleri vardır ve bu ilkeler evrensel olarak herkesi kapsar ve herkes için iyi ve doğrudur. Bu ilkeler etik ilklerdir. Örnek olarak doğru haber verme evrensel bir meslek ahlak ilkesidir. Önceden ortaya konulan bu etik ilkeye uyan gazetecinin sergilediği davranış etiktir.

3. İngiliz Filozof Stuart Mill ise bunun tam tersi bir anlayışı etik sayar ve buna Yararcı Etik Anlayışı denir. Bu kurama göre doğruyu ve yanlışı ayıran sonuçtur. Bir eylemin sonucu iyi ise o eylem ve o eyleme ulaşmada kullanılan yol iyidir. Yine İran'daki alternatif idam haberine dönecek olursak bu haberden sonra İran'da sözgelimi idam cezası kaldırılıyorsa veya bir başka doğru ve iyi eyleme yol açıyorsa bu haberin de etik olduğu iddia edilebilir.

Etik bağlamda internet ve devamında yeni medya ele alındığında Prof. Dr. Ersin Töreci (2014), Bilişim Dergisinde "İnternet Etiği" başlıklı yazısında şu görüşleri paylaşmaktadır:

"Genel olarak etik değerler konusunda toplumumuz ne kadar duyarliysa o kadar önem verildiği söylenebilir. Ancak belli bir rahatsızlık ortaya çıkınca ve başkaca akla gelen anlamlı bir düşünce olmayınca, kendi başına sanki bir çözüm olacakmış gibi "Sosyal medya etiğimiz yok" denebiliyor. ...... İnternet kullanımı ile iyice küreselleşmiş yeni dünyada belirleyici etken, bireylerin bilincidir. Yeteneklerini internet gibi özgür ortamlarda ortaya koyan bireylerin yaratıcılıklarını arttırabilmeleri, bizce düşüncelerine sınırlama getirmeden söylemlerini rahatsızlık verici olmaktan çıkarmaya özen göstermelerinden de geçiyor. İnternet etiği tanımlamanın amacı, özgür bir düşünce aktarma ortamı olan İnternet'te her düşünce rahatça sergilenirken her türlü olumlu fikrin ortaya çıkmasını sağlamaya yönelik olmalıdır. Kişilerin kendilerini geliştirici bir ortam olarak internetten yararlanabilmesi bu ortamın uygun kullanımın gerektiriyor. "İnternet Etiği" için yapılacak tanımların sosyal paylaşımı verimli ve etkin kılarken olumsuzlukları önleyici etken ise yine bireylerin kendi sağduyuları olacaktır...... Günümüzde bilişim toplumuna giden yolda aykırılıkların giderilerek nasıl başarılı olunacağı geniş olarak araştırılmaktadır. İnsanoğlunun, değişen dünyadan kopmadan, kendisine de yabancılaşmadan düşüncesini yeni duruma nasıl ayarlayabileceği, insani duygularını nasıl geliştirebileceği merakla beklenmektedir. Etik değerlerin rolü belirleyici olacaktır diye düşünebiliriz. Etik değerlerin pek fazla önemsenmediği ülkemizde sorunun evrensel standartlarda ele alınmasına devam etmeliyiz. Etik değerlerin her bireye, her duruma uygun geliştirilebilmesinin güçlükleri olsa da yararlı bir girişim, yapılması gereken bir çalışma olduğu, sürdürülebilmesi gerektiği konusunda geniş bir görüş birliğinin sağlanabileceğini umuyoruz" 


\subsection{Sosyal Medyada Etik Sorunlar}

Geleneksel medyadaki etik sorunlar devam ederken yeni medyanin ve onun içinde yer alan sosyal medyanın insanların hayatlarına girmesi hatta hayatlarının tam orta yerinde, merkezde yer almasıyla beraber, bu alanda da etik sorunlar baş göstermiş ve gündeme gelmeye başlamıştır. Özel yaşamım gizliliği başta olmak üzere, telif hakları, kullanıcının çok fazla reklamsal içeriğe maruz kalması, genel ahlaka aykırı paylaşımlar vb. gibi daha pek çok etik sorunlar sosyal medya için tartışılmaktadır.

2.2.1. Özel yaşamın gizliliği: Oya Araslı'ya göre bireyin genel yaşam alanı, kişinin herkesle paylaşabileceği kamuya açık yaşam alanlarını içerir. Özel yaşam alanı ise kişinin belirli kimselerle ve belirli ölçüde paylaştı̆̆ı yaşam parçalarını içerir (akt. Küzeci 2010: 71). Bireyin insan olmasından kaynaklı "insan onuru"nun temelinde yatan özel yaşamın gizliliği hakkı sosyal medyada çeşitli şekillerde ihlal edilmektedir. Bu ihlaller: Görsel işitsel malzeme paylaşımı, etiketleme özelliğinin kullanımı veya paylaşımların izinsiz aktarılması vb. (Binark ve Bayraktu$\tan$ 2013: 58).

2.2.2. İçeriğin asıl kaynă̆ının gösterilmemesi: Sosyal medya ortamında hemen hemen her konuda enformasyona hızla ulaşılabilmesiyle birlikte alıntılama ve "kopyala-yapıştır" içeriklerin de savaşı artmıştır. "Kopyala-yapıştır" başta internet gazeteciliği ve habercilikte görülse de dinamik sosyal medya içeriklerinin, türlerinin ve sayılarının artmasıyla birlikte tüm alanlarda görülebilmektedir. Şüphesiz internette ve sosyal medyada yayın yapan bir site, başka bir sitedeki bilgiyi dolaşımını artırmak amacıyla yayınlayabilir. Ancak söz konusu bilginin alıntılandığı özgün üretimi yapan kaynağın gösterilmeden yayınlanması intihalin sosyal medya ortamlarında en sik görülen biçimidir (Castells 2009'dan akt. Taş 2012: 253).

İçeriğin asıl kaynağının gösterilmemesi telif/patent haklarıyla ilgili konuyu gündeme getirmektedir.

2.2.3. Telif/patent hakları: Sosyal medyada dolaşımda olan her içerik gibi telif ve patent haklariyla korunan içerikler de birer enformasyondur. Enformasyonun paylaşımı ise temelde etik bir sorun değildir. Ancak telif ya da patent hakkına sahip kişi ya da kuruluşların enformasyonun sınırsızca dolaşması karşısında uğradıkları hak kayıpları da görmezden gelinemez. Bu noktada belirleyici unsurlardan biri, ticari kayıplar ile etik sorunlar arasındaki farkın doğru biçimde kurulmasıdır. Başka bir kişi ya da kuruluşun emeği ile kazanç elde etmek korsanlık veya haksız kazanç olarak tanımlanmaktadır ve bu durum hem ticari hem etik açıdan sorunludur. Ancak kazanç elde etmenin olmadığı durumlarda örneğin, "herhangi bir kullanıcının eline bir şekilde ulaşmış olan içeriği başka kullanıcı(lar) kazanç amacı olmaksızın paylaşması etik bir sorun mudur?" sorusunun 
yanıtıyla ilgili tartışmalar sürmektedir. Telif hakları ihlallerinin eski bir sorun olduğunu ortaya koyan pratiklerden birisi de intihaldir. Yeni enformasyon teknolojileri intihal sorununun mecralarını daha yaygın ve çeşitli kılmıştır. Örneğin bazı internet siteleri link verme yoluyla alternatif ya da rakip olabilecek sitelerin kullanıcılarını da kendi sitelerine çekerek link verilen sitenin telif haklarını ihlal edebilmektedirler (Uzun 2005: 61).

\subsection{4. Üretilen içeriklerin olgunlaşmadan ve doğruluğunun teyit edilmeden ya-} yılması: Geleneksel medya için geçerli olan "haberin/olayın doğruluğunu teyit etmek" sosyal medya için de geçerliliğini korumaktadır.

Sosyal medyada enformasyonun işlenmesi anlamında, hem haberin hem de bilgi veren unsurların doğruluğunun kontrolü gerekmektedir, bir başka ifadeyle, içeriğin üretiminde hem kamuya sunulabilir hem de reklam içeriğinden ya da tanıtıcı içerikten ayırt edilebilir bir içerik elde etmek için editöryal kontrole ihtiyaç duyulmaktadır (Deuze ve Dimoudi 2002: 90). Ancak sosyal medyanın kullanıc1 türevli olmaları nedeniyle bu tür kontrollerin yapılması zordur. Kullanıcılar, duyduğu bir haberi doğruluğunu kontrol etmeden, araştırmadan paylaşmaktadır. Böylelikle de bilgi kirliliği ortaya çıkmakta ve etik sorunlarla karşılaşılmaktadir.

2.2.5. Kişisel verilerin güvenliğinin sağlanamaması: Kişisel veri; bireyin şahsi, mesleki ve ailevi özelliklerini gösteren, o bireyi diğer bireylerden ayırmaya ve niteliklerini ortaya koymaya elverişli her türlü bilgi anlamına gelmektedir (Şen 2014).

Teknolojinin getirdiği dezavantajlardan biri, verilerin güvenli şekilde saklanamaması ve bir şekilde başkasının eline geçebilme olasılığıdır.

Kişisel verilere yönelik tehdit kaynakları devlet temelli, çeşitli grupların girişimleri temelinde veya özel şirketlerin çıkarları temelli ortaya çıkabilir. Kişisel verilerin korunması, kişilere ilişkin verilerin toplanmasını, saklanmasını, kullanılması$\mathrm{n} 1$ ve veri eşleştirmeden oluşan veri işleme sürecinin tüm aşamalarını kapsar. Sosyal medya ortamlarında paylaşılan bilgiler kişisel bilgilerden oluşan bir veri tabanı oluşturabilir. Sosyal medya ortamlarında artan tecimsellik, kişisel verilerin güvenliğinin sağlanması gerekliliğini ortaya koyan en önemli gelişmedir (Binark ve Bayraktutan 2013: 73).

2.2.6. Veri madenciliği: Veri madenciliği, büyük ölçekli veriler arasından bilgiye ulaşma, bilgiyi madenleme işidir ya da bir anlamda büyük veri yığınları içerisinden gelecekle ilgili tahminde bulunabilmeyi sağlayabilecek bağıntıların bilgisayar programı kullanarak aranmasıdır (http://tr.wikipedia.org).

Sosyal medya ortamlarında kullanıcıların verilerinin işlenmesi ve ortamda bırakılan dijital izler üzerinden yapılan veri eşleştirmesi ile kullanıcılara yönelik pro- 
fil bilgileri çıkartılmaktadır. Buna göre şirketler ürünlerini daha iyi pazarlayabilmek için kullanıcıların kişisel bilgilerini toplayıp, onları belirli özelliklerine göre sinıflandırmaktadır. Bunun yanında tüketici internette bir sayfaya girip bir alışveriş yaptığında kendisi hakkında dijital bir iz bırakır. Ancak şirketler yalnız alışveriş sırasında kullanıcıların kişisel bilgilerini toplamaz, aynı zamanda kullanıcıların hangi sitelere girdiklerini, sosyal ağlarda nelerden hoşlandıklarını, hangi konuları izlediklerini, e-postalarında hangi kelimeleri kullandıklarını takip ederek bu kullanıcılara göre pazarlama stratejileri geliştirirler. Bu toplanan kullanıcı verilerini şirketler yalnız kendileri için kullanmaz, kullanıcının bilgisi ve rızası olmadan başka şirketlere de satarlar (Arslantaş ve ark. 2012).

Örneğin; bir alışveriş sitesinde kadın ayakkabı mağazası gezildi. Daha sonra başka internet sitelerine girildiğinde daha önce gezilen ayakkabı mağazasının reklamları, yaptığı kampanyalar ile karşılaşılmaktadır. Aynı durum defalarca yaşanabilmektedir. Bu, veri madenciliğidir. Yani internette ayak izi bırakmak gibidir.

2.2.7. Dijital gözetim olgusu: Antony Giddens, sayısallaşma ve gözetimi modernitenin bir sonucu olarak ele almıştır ve modernizm içinde gözetim ile gözetlemenin iki farklı anlamina değinmiştir: İlki, gözetim şifrelenmiş bilgi birikimidir. Burada kişilerin nesneler haline getirilerek kodlanmasından, sayılmasından bahseder. Toplanan bilgiler, sadece basit bir bilgi toplama işlemi değildir; toplanan bu bilgiler belli bir sınıflama ve ayırt etme işlemi de içerdiği için nitelikli bir bilgi depolama işlemidir (Giddens 2008: 24).

Gündelik yaşamın birçok alanı güvenlileştirme söyleminin meşru kılınması ve risk yönetimi amacıyla dijital olarak gözetlenmektedir: Kentte kamusal alanları kuşatan MOBESE kameralar, TC. kimlik kartı ile yapılan işlemler, parmak izi ve iris tarama ile girip çıkılan iş yerleri, biyometrik bilgileri içeren kartların yaygınlaşması vd.'ni düşünülecek olursa, Türkiye'de yurttaş artık oldukça kapsamlı ve entegre bir elektronik veri tabanının içinde sayısal bir varlık haline gelmiştir. Ticari kayıtlayıcılar da yurttaşın haberi, bilgisi veya izni olmaksızın, ya da iznini hiç talep etmeksizin dijital verileri birbiri ile eşleştirmekte, tüketici profillemesi yapmak amacıyla bu verileri kullanmaktadır (http://bimo.org.tr)

Dijital gözetim olgusu, hem dünyada hem de Türkiye'de ulus-devletin güvenlilikleştirme söylemi bağlamında insanların denetlenmesi ve baştan "olağan şüpheli" olarak konumlandırması, dijital takibi sürecinde yaygın olarak gerçekleşen bir hak ihlalidir (Altıparmak 2013).

Dijital gözetim olgusu, veri madenciliği özelliğiyle birlikte ele alınmalıdır. Sosyal medyada veri madenciliği gibi, internet sitelerinde gezilen web sayfaları nasıl ki kayıtlı tutuluyorsa dijital gözetimde de aynı şey söz konusudur. Sosyal medyada yapılan herşey dijital olarak gözetlenmektedir. 
2.2.8. Haber ve ticari enformasyonun sınırlarının belirsizleşmesi: Sosyal medya ile birlikte haber ve reklam kavramları uygulamada iç içe geçmiştir.

İnternet sitelerinin ve çevrimiçi haber uygulamalarının başlıca gelir kaynakları, tıpkı televizyon yayıncılığında olduğu gibi reklam gelirleridir. Ancak sosyal medyanın özellikleriyle birlikte, reklamların televizyonda olduğunun aksine genellenen bir çoğunluğa ulaştırılması yerine, özgül özellikleri tanımlanabilen belirli kişiler ya da gruplara ulaştırılması olanaklıdır. Bu noktada kullanıcıların ilgilerini belirli reklamlara çekebilmek için çoğunlukla reklamların habermiş gibi sunulduğu gözlemlenmektedir. Diğer taraftan yeni medyanın hipermetinsellik ve etkileşimsellik özellikleri, asıl haber metinleri içindeki bazı kelimelerin kullanıcıyı "reklama yönlendiren" anahtar noktalar olarak kullanılabilmesini de olanaklı kılmaktadır (Binark ve Bayraktutan 2013: 80).

2.2.9. Yoğun reklam içeriği: Sosyal medyada reklamlar, geleneksel medyaya oranla çok daha rahat ve kuralsızca yayınlanabilmektedir. Geleneksel medyada reklam yayınlama belli kurallar çerçevesinde yapılmakta iken, sosyal medyada bu durum değişmiştir.

Kullanıcı sürekli reklamsal içeriğe maruz bırakılmaktadır ve istediği bilgiye ulaşabilmek veya istediği sayfaya gelebilmek için o reklamı izlemek durumundadır.

Örneğin bir haber sitesinin web sayfasına girildiğinde ilk olarak kullanıcının karşısına otomobil veya ayakkabı-giyim vb. gibi reklamlar çıkmaktadır. Yaklaşık 20 saniye devam eden bu reklamları kullanıcı kapatmak istese de pencerenin kapanma süresine kadar reklamı izlemektedir.

2.2.10. Yanıltıcı etiketleme ve başlıklandırılma: Ticari web sitelerinin temel gelir kaynakları reklamlardır. Bu anlamda reklamları olabildiğince fazla internet kullanıcısına ulaştırabilmek, web sitesinin ve sosyal medyanın temel amaçlarından biri haline gelmektedir. Bu amaca ulaşabilmek için sosyal medyada çoğunlukla bilerek yanlış ve sansasyonel etiketleme ve başlıklandırma kullanılmaktadır. Böylelikle internette gezinen sosyal medya kullanıcıları, karşılaştığı sansasyonel başlık veya etiketi merak ederek bağlantıyı açmakta ve o sayfadaki içeriğin ne olduğunu öğrenirken, çok sayıda reklamı da bilgisayarında görüntülemektedir (Binark ve Bayraktutan 2013: 84).

$\mathrm{Bu}$ etik sorun, yukarıda bahsedilen kullanıcının yoğun reklam içeriğine maruz kalması ile paralel olarak değerlendirilebilmektedir.

2.2.11. Nefret söyleminin varlĭ̆ı: Nefret söylemi, her türlü hoşgörüsüzlükten kaynaklanan ve önyargılardan beslenen nefreti yayan, teşvik eden, savunan ya da haklı çıkaran ifade biçimleri için kullanılmaktadır. Nefret söylemi ile nefret duygusunu birbirinden ayırt etmek gerekir. Nefret duygusu herkeste olabilen bir 
duygu türü iken, bu duyguyu söylemlerinde dile getirmek veya eyleme dönüştürmek nefret söylemini açığa çıkarmaktadır. Sosyal medyadaki içeriklerde nefret söylemleri ve bunların kontrol edilememesi de etik ihlaller arasındadır. Sosyal medya içeriklerinin kullanıcılar tarafından yönetiliyor olması bu etiğin kuralın ihlal edilmesine yol açmaktadır.

Nefret söyleminin, yaygınlaşarak dolaşıma girmesi, nefret suçlarına da zemin hazırlamaktadır. Bu konuda OSCE ODIHR (Demokratik Kurumlar ve İnsan Hakları Birimi), nefret suçu ve nefret söylemi arasında da bir bağ olduğu belirtilir. Doğrudan bağ olduğunun kanıtlanması zor olsa da, nefret temelli şiddetin çoğunlukla nefret söylemi içerisinde ortaya çıktığının altını çizer. ODIHR, örgütlü nefret gruplarının fikirlerini çeşitli yayınlar, popüler müzik, Internet ve gösterilerle dile getirdiklerinin altını çizerek bu eylemlerin nefret söylemini ve nefret suçlarını normalleştirmeye ve meşru kılmaya yönelik olduğu saptamasında bulunmaktadır (ODIHR 2009: 53).

Nefret söylemi türleri genelde altı başlık altında toplanmaktadır (Binark ve Çomu 2012):

-Siyasal nefret söylemi: Siyasal bir düşünceyi ve bu düşüncenin takipçilerini hedef alan nefret söylemidir.

-Kadınlara yönelik nefret söylemi: Temelde cinsiyetçi ifadelerden başlayıp daha ileri boyutlarda ele alınabilmektedir. Çoğunlukla açık nefret biçiminde ortaya konulmazlar. Ancak kadınların yaptıklarının ya da yapmadıklarının eleştirilmesi şeklinde görülmektedir.

-Yabancılara ve göçmenlere yönelik nefret söylemi: Yabancıları, göçmenleri ve/veya etnik grupları hedef alabilmektedir.

-Cinsel kimlik nedenli nefret söylemi: Farklı cinsel kimliklere ve cinsel kimlik yönelimine sahip kişileri hedef alan nefret söylemidir.

-İnanç ve mezhep kökenli nefret söylemi: Farklı din ve mezheplere sahip kişi ya da gruplara yönelik olarak üretilebilmektedir.

-Engelli ve çeşitli hastalıklara yönelik nefret söylemi: Fiziksel veya zihinsel engellilere ya da bazı hastalıklara sahip kişilere yönelik üretilmektedir. Türkiye'de görülme sıklığı giderek artmaktadır.

\subsubsection{Bireyin sosyal medya ortaminda sadece tüketici olarak konumlandırıl-} ması: Yüksek etkileşimsellik barındıran sistemlerin (web 2.0) yaygınlaşmasıyla birlikte artan bir biçimde internet kullanıcıları bu ortamlarda çoğunlukla "tüketici" olarak konumlandırılmaktadır. Oysa mevcut tablo farklı bir durumu yansıtmaktadır. En çok ziyaret edilen web sitelerine bakıldığında bu sitelerin çoğun- 
lukla kullanıcı türevli içeriklerin dolaşıma sokulduğu ya da paylaşıldığı ortamlar olduğu görülmektedir. Bu ortamların Türkiye' de ve dünyada en çok ziyaret edilen siteler olması, bireylerin yalnızca tüketici değil aynı zamanda da üretici olduklarının da bir göstergesidir. Bireyin tüketici olarak konumlandırılması çeşitli yeni medya uygulamalarındaki aşırı reklama maruz kalma olgusunu da içermektedir (Binark ve Bayraktutan 2013: 95).

2.2.13. Genel ahlaka aykırı içerik oluşturmak ve yaymak (Mavnacıoğlu 2009: 64): Çocuk ve gençlerin de yeni medya ortamların da bulunabileceği göz ardı edilerek, hem onların fiziksel, psikolojik ve cinsel gelişimlerini olumsuz yönde etkileyebilecek hem de genel ahlak kurallarıyla bağdaşmayan paylaşımların yapılması en önemli etik ihlalleri arasındadır.

2.2.14. Anonimlik olgusu: Anonimlik olgusuna, sahte kimlikli kullanıcı da denebilir. Kullanıcıların sahte kimlik oluşturarak sosyal medyada hesap açması, serbestçe fikir alışverişinde bulunması, tartışmalara girmesi, çeşitli hareket veya örgütlere destek vermesi mümkündür. Sahte kimlikli kullanıcıların diğer kullanıcıların kişilik vb. haklarını ihlal etmesi de etik kuralın çiğnenmesi olarak karşımıza çıkmaktadır.

2.2.15. Trol olgusunun görülmesi (Spam blog): Trol, internette insanların keyfini kaçırmak ya da münakaşa başlatmak için tohum ekmeye çalışan; forumlar, bloglar, sohbet odaları gibi çevrimiçi topluluklarda kasten alevlendirici, konu ile ilgisi olmayan mesajlar göndererek okuyucuları provoke edip duygusal cevaplar verdirtme ya da bir başlı̆̆ın konusunu dağıtma niyetinde olan kişilerdir (http://tr.wikipedia.org/wiki/Trol).

Bu sorun kullanıcı türevli içerik üretimi ile doğrudan ilgilidir. Spam blog göndermekle trol olgusu aynidir.

İnternet kullanıcılarının kendilerini ifade etmek, mesleki deneyimlerini, bilgi ve görüşlerini paylaşmak yerine sadece para kazanmak amacıyla içerik oluşturmaları ve diğer kullanıcılarla paylaşmaları sosyal medyanın amacına ters düşen davranışlardandır. Sadece reklam almak amacıyla "spam blog" olarak adlandırılan blogların oluşturulduğu görülmektedir. Kullanıcıların para kazanmayı birincil amaç haline getirmeleri oluşturulan içerikleri etik açıdan sorunlu hale getirmektedir (Mavnacioğlu 2009: 68).

2.2.16. Dil: Sosyal medyada her şeyden önce yeni bir iletişim dili ve kimlik inşa edilmektedir. Teknolojik ilerlemeye bağımlılığı nedeniyle takibi neredeyse imkânsız olan bu yeni dil, bireylerin hem üretim hem de tüketim kaynağ gelmesiyle çoğulcu, ama denetlenemez ve öngörülemez bir mecrada vücut bulmuştur. Herhangi bir aracın kendisi bizatihi iyi ya da kötü değildir. Beşeri unsurun tavrı, eşyanın işlevini belirler. Mesela, insanı mağdur eden televizyon veya 
internet değildir; kötü televizyonculuk ya da kötü internet kullanımıdır (Küçükyılmaz 2013). Kullanıcı türevli özelliği ve her kesimden kullanıcının sosyal medya ortamında bulunması nedeniyle dilin kullanımı konusunda sıkıntılar yaşanmaktadır. Dili kullanan bireylerdir ve sosyal medyada kullanılan anlamsız k1saltmalar, yabancı terimler kullanıcılar tarafından türetilmektedir, bu da dilin yozlaşmasına neden olmaktadır.

Sosyal medyada tartışılan etik sorunların temeli, kullanıcıların içerik oluşturmasından kaynaklanmaktadır. Sosyal medyaya hiçbir kısıtlama, şart olmadan herkes girebilmekte ve paylaşımlar yapabilmektedir. Bu paylaşımlar, hiçbir şekilde denetimden geçmediği için de etik ihlalleri doğurmaktadır.

\subsection{Sosyal Medyada Var Olan Etik Sorunların Nedenleri}

Sosyal medyada karşılaşılan etik sorunların başlıca 3 nedeni bulunmaktadır. Bunlar (Binark ve Bayraktutan 2013: 113-115):

1-Siyasi nedenler: Bu nedenler arasında iktidar/güç mücadelesi ile karşılaşılmaktadır. Ellerindeki mevcut iktidarı/gücü kaybetmemek için çıkarları doğrultusunda sosyal medyaya sansür veya denetim uygulamaya kalkışarak etik ihlallere neden olmaktadirlar.

2-Ekonomik nedenler: Yeni medya teknolojilerini ellerinde tutan kapitalist girişimler sosyal medyadaki etik ihlallerin ekonomik nedenlerini teşkil etmektedir. Kullanıcıların yoğun reklamsal içeriğe maruz kalması, haber/reklam ayrımının ortadan kalkması gibi unsurlar etik ihlallere neden olmaktadır.

3-Kültürel nedenler: Kişilik haklarının ihlali, mahremiyetin çiğnenmesi vb. pek çok konuda bilinç ve eğitim eksikliği de etik ihlallerin kültürel nedenleri arasındadir.

\subsection{Sosyal Medyada Etik Sorunlar Karşısında Alınan Tavır}

Her yeni teknoloji yaşam kolaylığı sağlamasının yanında etik sorunları da beraberinde getirebilmektedir. Tıpkı geleneksel medyanın her bir parçasının ortaya çıktığı andan itibaren etik tartışmalara konu olması gibi, bugün de yeni medyanın bir parçası olan sosyal medyanın etik sorunlarıyla karşı karşıya bulunulmaktadır. Sosyal medyadaki etik sorunlara her geçen gün yeni bir madde daha eklenmektedir.

Sosyal medyayı herkes kullanmaktadır. Ancak kullanıcıların çok az bir kesimi bu ortamlardaki etik ihlallerine ve güvenliğe dikkat etmektedir. Özellikle Facebook gibi hem fotoğraf, hem video, hem yazı paylaşımı yapılan sosyal medya ortaminda kullanıcilar yapılan yorumlar nedeniyle birbirleriyle (birbirlerini tanımasalar da) ağız dalaşına girebilmektedir. Bu tür davranışlar içinde bulunan kullanıcılar için zaten etik, güvenlik vb. konular umursanmamaktadır. 
Sosyal medyayı bilinçli bir şekilde kullanan kullanıcılar, tartışmaya açık olabilecek ve sorun yaratacak yorumlardan uzak durmaktadırlar. Fotoğraf, konum vb. sorun yaratabilecek paylaşımlar, kullanıcılar için her zaman büyük bir risk ve tehdit olabilmektedir. Bunun bilincinde olan kullanıcılar sosyal medya ortamlarında paylaşımlarını minimum seviyede tutma gayreti içindedirler ya da paylaşım yapmayıp sadece izleme konumunda kalmaktadırlar.

Çocuklu aileler için aslında durum biraz daha sıkıntılıdır. Pornografi dahil her tür içeriğin yer aldığı sosyal medya ortamından aileler çocuklarını korumak zorundadırlar. Bilinçsizce paylaşım yapan ve yaşadığı her anı bu tür ortamlarda paylaşan çocuklar aslında kendilerini bekleyen tehlikenin farkında değildirler. Çocuklarının bilgisayarda girdiği sitelerin kontrolünü eline alan aileler olduğu gibi çocuklarının sokağa çıkmasındansa gözünün önünde oturmasını tercih eden aileler de bulunmaktadır. Bu tür aileler, çocuklarının sosyal medya ortamlarında neler yaptığını, neler paylaştığını veya ne tür mesajlara maruz kaldığını kontrol etmek durumundadırlar ki, bunu yapan aile sayısı oldukça sınırlıdır. Kendilerinin maruz kaldığı mesajları bile sorgulamayan ebeveynlerin çocuklarını bu durum karşısında korumaları pek mümkün gözükmemektedir.

Sosyal medyada kullanıcılar içerik oluşturduğu sürece etik sorunların yaşanması devam edecektir. Çünkü her kullanıcı içerik oluştururken kendilerine göre haklı nedenlerle ve farklı amaçlarla hareket etmektedir. Kimi içerik herhangi bir sorun oluşturmazken hatta kullanıcılar açısından faydalıyken kimi içerik ise hem içeriği üreten açısından hem de içeriği dağıtan açısından etik ve hukuki sorun oluşturmaktadır. Sosyal medya, kullanıcı odaklı olduğu için bazı etik dışı sorunlar hukuki boyutlara taşınmamaktadır. Etik dışı davranışlar, ticari konularda, telif hakları ve kişilik haklarına saldırı durumlarında hukuki boyuta taşınmaktadır (Mavnacioğlu 2009: 71).

Son dönemde etik ihlallerin denetlenmesi konusunda bir çaba içinde olunduğu görülmektedir.

Türkiye Büyük Millet Meclisi Bilişim ve İnternet Komisyonu tarafından 2013 yılında bir rapor hazırlanmıştır. Rapor, her şeyden önce bilişim alanı ile toplumsal yaşam arasındaki dengeyi kurmaya dönük öneriler içermektedir. Yeni medya yerine ağırlıklı olarak bilişim ve internet kavramlarının öne çıkması, çalışmanın teknik yönünün baskın olduğunu göstermektedir. Bu nedenle, rapor, internet medyasının ve dolayısıyla da sosyal medyanın hukuki anlamda organize edilmesine odaklanmış görünmektedir. Bunlar elbette çok önemli ve hızlı bir biçimde hayata geçirilmelidir (Küçükyılmaz 2013).

Sosyal medyadaki etik ihlaller konusundaki bir diğer çabayı da, gerek bir komisyon kurarak bilişim sektöründe çalışanların uyması beklenen davranış biçimlerini belirleyen ve gerekse de "İnternet iletişim kuralları" adı altında internet etiği- 
ne ilişkin Türkçe bir metin hazırlayan Türkiye Bilişim Vakfı (TBV) göstermektedir. TBV'nin internet iletişim kuralları metni şu şekilde özetlenebilir: Başkalarına karşı saygı, biçimsel özen, içerik ile ilgili özen, öteki konular (Erol 2009). Bu kurallar sosyal medya için de geçerlidir.

\subsection{Sosyal Medyadaki Etik İhlallere Karşı Öneriler}

Sosyal medyada yukarıda belirtilen etik ihlallerine karşı kullanıcılara, içerik sağlayıclara ve düzenleyici kurullara sorumluklar düşmektedir. Yapısal olarak sosyal medya, sohbet ve dedikodu mantığıyla işlediği için bireyler arasında etik dişı davranışlar bireyler farkına varmasalar bile gerçekleşmektedir.

İçerik sağlayıcılar, etik dışı davranışları önlemek için şu uygulamaları hayata geçirmelidirler (Mavnacıoğlu 2009: 70):

- İçerik oluşturanlarla ilgili daha etkin bir kimlik ve veri doğrulama sistemine gidilmelidir.

- Filtre sistemi sayesinde sahte profillerin önüne geçilmelidir.

- Veri gizliliği doğrultusunda verilerin ortak paylaşımda kopyalanmasına sinırlama getirilmelidir.

- Kullanıcı sözleşmesinin yanı sıra bağlayıcılığı olan etik sözleşme hayata geçirilmelidir.

Düzenleyici kurullar, etik dışı davranışları önlemek için şu uygulamaları hayata geçirmelidirler (Mavnacıŏ̆lu 2009: 71):

- Sosyal medyanın kendine özgü yapısını dikkate alarak içerik paylaşım, oluşturma ile ilgili hukuki ve etik sınırların belirlenmesi gerekmektedir.

- Uluslararası içerik sağlayıcılarla etik dışı ve zararlı içerikle mücadele konusunda işbirliği yapılmalıdır.

- Bunlar sonucunda etik dışı içerik yüzünden bütün kullanıcılar cezalandırılmamalı sadece o etik dışı davranışı gerçekleştiren kullanıcı sorumlu tutulmalıdir.

Her ne olursa olsun asıl büyük sorumluluk kullanıcıya düşmektedir. İçerik sağlayıcı veya düzenleyici kurulların denetim ya da alacağı tedbirler kullanıcının özdenetiminden daha etkili olamayacaktır. Önemli olan sosyal medya kullanıc1larının bu ortamlarda kendilerini ve çocuklarını bekleyen tehlike ve risklerin farkına varmalarıdır.

Kullanıcının sosyal medya ortamlarında etik ihlallere karşı özdenetim sağlaya- 
bilmek amacıyla geleneksel medya için hayata geçirilen medya okuryazarlığının yeni medya ve kapsamında bulunan sosyal medya için de hayata geçirilmesi gerekmektedir (Binark ve Bayraktutan 2013).

\section{SONUÇ}

Sosyal medyanın hayatımıza getirdiği pek çok kolaylığı ve teknolojisi yanında etik kuralları ihlal etmesi bir sorun olarak karşımızda durmaktadır. Sosyal medyanın kullanıcı türevli olması, siyasilerin gücü ellerinde bulundurmak istemesi ve ticari kazanç sağlamak isteyenlerin etik ihlallere neden olduğu bir gerçektir.

Kullanıcıların sosyal medya ortamlarında paylaşım sınırlarını çizememesi, özel hayata dair herşeyi paylaşması, kişisel bilgilerini cömertçe ortaya koyması, bulunduğu yerlerde beraber olduğu kişileri etiketlemesi güvenlik sorunlarına neden olabilmektedir. Kendileri dışında çocuklarının da sosyal medya ortamlarında fütursuzca bulunmasinı denetlememeleri/denetleyememeleri sonucunda da kavramın tam tersi "asosyal" bir neslin yetişmesine engel olamamaktadırlar.

Sosyal medya ortamlarında özel yaşamın gizliliği, kullanıcıların yoğun reklamsal içeriğe maruz kalması, dilin kullanımı, genel ahlaka aykırı içerik paylaşımı, spam bloglar, sahte kimlikli profiller, yanıltıcı etiketleme ve başlıklandırılma ve nefret söylemleri etik ihlaller arasındadır.

Sosyal medya ortamlarında kullanıcıların silinen bilgilerinin dahi bellekte depolandığı akıldan çıkarılmamalıdır. Facebook vb. birçok sosyal ağ, kullanıcılarının bilgilerini satmaktadırlar. Örneğin, sosyal ağlarda sözlü veya nişanlı olduğu belirten kullanıcılara mobilya, gelinlik-damatlık, ev dekorasyonu vb. dügünle ve evlilikle ilgili bilgi ve reklam içeren e-postalar firmalardan gelebilmektedir. Bir başka örnek ise, sosyal ağlarda yapılan mesajlaşmalarda araba satın alacağını yazan bir kullanıcıya da otomobil firmalarından e- postalar gelmektedir. Bu da, firmaların kullanıcıların evlilik hazırlığı içinde olduklarını veya otomobil almak için araştırma yaptıklarını bildiklerinin bir göstergesidir.

Etik ihlaller karşısında içerik sağlayıcı ve denetim kurullarına sorumluklar düşmektedir. Ancak en büyük sorumluluk kullanıcılara aittir. İnternette paylaşılan hiçbir bilginin gizli olmadığı göz önüne alınarak paylaşımlar yapılmalı, hatta mümkünse paylaşımlar minimum seviyede olmalı, gizli kalması gereken bilgiler internette paylaşılmamalıdır. Her ne kadar etik ihlaller karşısında yasa koyucular, kurullar, dernekler tarafından bir çaba harcansa da hiçbir çaba kullanıcının bilinçli olması ve özdenetimi kadar etkili olamayacaktır.

\section{KAYNAKLAR}

Akter T (2009) Merkeziyetsiz Medya: İnternet ve Etik, Fırat Üniversitesi İletişim Fakültesi Medya ve Etik Semp, 07-09 Ekim 2009, Elazı̆̆. 
Altıparmak K (2013) http://www.turk-internet.com/portal/yazigoster.phd? yaziid= 42879\# , erişim tarihi: 27.03.2015.

Arslantaş S, Binark M, Dikmen E Ş, Fidaner I B, Küzeci E ve Özaygen A (2012) Türkiye'de Dijital Gözetim: T.C. Kimlik Numarasından E-Kimlik Kartlarına Yurttaşın Sayısal Bedenlenişi, http://ekitap.alternatifbilisim.org/turkiyede-dijitalgozetim.html, erişim tarihi: 27.03.2014, 39-110.

Atabek Ü (2005) İletişim Teknolojileri ve Yerel Medya İçin Olanaklar, Sevda Alankuş (ed), Yeni İletişim Teknolojisi ve Medya, IPS İletişim Vakfı Yayınları, İstanbul, 61-90.

Binark M (2007) Yeni Medya Çalışmaları, Dipnot Yayınları, Ankara.

Binark M ve Bayraktutan G (2013) Ayın Karanlık Yüzü: Yeni Medya ve Etik, Kalkedon Yayınları, İstanbul.

Binark M ve Çomu T (2012) Sosyal Medyanın Nefret Söylemi İçin Kullanılması İfade Özgürlüğü Değildir!, https://yenimedya.wordpress.com/2012/01/20/sosyalmedyanin-nefret-soylemi-icin- kullanilmasi-ifade-ozgurlugu-degildir/, erişim tarihi: 17.04.2014.

Binark M ve Löker K (2011) STÖ’ler İçin Bilişim Rehberi, STGM, Ankara.

Coleman B (2012) Hello Avatar, Emrah Bilge (çev), Mediacat Yayınları, İstanbul.

Çavdar G (2009) Kamu Hizmeti Yayıncılığı ve Etik, Fırat Üniversitesi İletişim Fakültesi Medya ve Etik Semp, 07-09 Ekim 2009, Elazı̆̆.

Demir V (2006) Medya Etiği, Beta Yayınları, İstanbul.

Deuze M ve Dimoudi C (2002) Online Journalists in the Netherlands: Towards a Profile of a New Profession, Journalism Studies, 3 (1), 85-100

Erol G (2009) Medya ve Etik: İnternet Haberciliğinde Nesnellik, Etik İlkelerin İçeriği, Uygulamadaki Sorunlar ve Televizyon Haberciliği İle Karşılaştırılması, Fırat Üniversitesi İletişim Fakültesi Medya ve Etik Semp, 07-09 Ekim 2009, Elazı̆̆.

Giddens A (2008) Ulus Devlet ve Şiddet, Kalkedon Yayınları, İstanbul.

Gürel T (2009) Kurumsal Sosyal Sorumluluk ve Etik Kavramlarının Kuramsal Bağ1 Üzerine Bir İnceleme, Fırat Üniversitesi İletişim Fakültesi Medya ve Etik

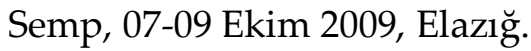

http://tr.wikipedia.org/wiki/Trol_(\%C4\%B0nternet), erişim tarihi: 14.05.2015

http://tr.wikipedia.org/wiki/Veri_madencili\%C4\%9Fi, erişim tarihi: 13.05.2015

http://tr.wikipedia.org/w/index.php?title=Sosyal_medya\&veaction=edit\&vesectio $\mathrm{n}=7$, erişim tarihi: 15.05 .2015 .

http://www.meb.gov.tr 
http://www.sabah.com.tr/fotohaber/teknoloji/facebookta-facebook-fotograflarlafacebook-tuneli?tc=22\&page $=11$, erişim tarihi: 13.05 .2015

http://www.teknolojioku.com/haber/messengerim-skype-oldu-ne-yapmaliyim9357.html, erişim tarihi: 10.04.2015

http://bimo.org.tr/wp-content/uploads/2011/08/internet-raporu-16Nisan2012v0.5.pdf, “8-21 Nisan 2013 16. İnternet Haftası 20. yaşında Türkiye'de Internet'in Durumu Raporu", erişim tarihi: 14.05.2015

http://dijitalkulturgra331.blogspot.com.tr/2013/01/yeni-medya-ve-gelenekselmedya-sunum.html, erişim tarihi: 14.05.2015

http://www.bilisimdergisi.org, erişim tarihi: 27.03.2014

http://www.ahmetcetinkaya.com/wpcontent/uploads/2015/03/Yeni_Medy ada_Yayincilik_Uygulamalri_Sunu_1.pdf, erişim tarihi: 13.05.2015

http://tr.wikipedia.org/wiki/ENIAC, erişim tarihi: 13.05.2015

http://tr.wikipedia.org/wiki/Flickr, erişim tarihi: 13.05.2015

http://sosyalmedya.co/sosyal-medyanin-tarihi, erişim tarihi: 13.05.2015

http://www.trendweek.com/sosyal-medya-nedir/, erişim tarihi: 15.05.2015

Jenkins H (2006) Convergence Culture:Where Old and New Media Collide, New York University Press, New York.

Kaplan A ve Haenlein M (2010) Users of The World Unite! The Challenges and Opportunities of Social Media, Business Horizons, 53(1).

Küçükyılmaz M (2013) Sosyal Medyada Henüz Reşit Olamadık, Star Gazetesi, 16.02.2013.

Küzeci E (2010) Kişisel Verilerin Korunması, Turhan Yayınları, Ankara.

Lievrouw L A ve Livingstone S (2007) The Social Shaping and Consequences of ICTs, The Handbook of New Media, Sage Pub. London.

Lister M, Dovey J, Giddens S, Grant I ve Kelly K (2009) New Media: A Critical Introduction, Routledge, New York.

Mavnacioğlu K (2009) İnternette Kullanıcıların Oluşturduğu ve Dağıttığı İçeriklerin Etik Açıdan İncelenmesi: Sosyal Medya Örnekleri, Fırat Üniversitesi İletişim Fakültesi Medya ve Etik Semp, 07-09 Ekim 2009, Elazı̆̆.

ODIHR (2009) Hate Crime Laws A Practical Guide, http://www.osce.org/odihr /36426?download =true, erişim tarihi: 28.03.2015.

OECD (2008) Measuring User-Created Content: Implications for the ICT Access and Use by Households and Individuals Surveys, http://www.oecd.org/ dataoecd/ 44/58/40003289.pdf., erişim tarihi: 11.05.2012. 
Sanlav Ü (2014) Sosyal Medya Savaşları, Hayat Yayınları, İstanbul.

Şen E (2014) Kişisel Verilerin Kaydedilmesi, http://www.haber7.com/yazarlar/ prof-dr-ersan-sen/1235168-kisisel-verilerin-kaydedilmesi, erişim tarihi: 14.05. 2015.

Taş O (2012) Gazetecilik Etiğinin Meslek Sınırları: Profesyonellik, Piyasa ve Sorumluluk, İletişim Yayınları, İstanbul.

Töreci E (2014) İnternet Etiği, http://bilisimdergisi.org/s158, erişim tarihi: 27.03.2014.

Uzun R (2005) Haber ve Telif Hakları, İnternet Gazeteciliğinde İntihal, İletişim Yayınları, İstanbul.

Van Dijk J (2004) Digital Media, The Sage Handbook of Media Studies, John D H Downing, Denis McQuail, Philip Schlesinger, Ellen Wartella (eds) Sage , London, 145-164.

Yengin D (2012) Yeni Medya ve Dokunmatik Toplum, Derin Yayınları, İstanbul 